July 2016

\title{
Important strategies for effective family planning counseling
}

Savera Aziz Ali

Aga Khan University, savera.azizali@aku.edu

Minaz Mawani

Aga Khan University, minaz.mawani@aku.edu

Gulshan Bano

Aga Khan University

Sumera Aziz Ali

Aga Khan University, sumera.ali@aku.edu

Follow this and additional works at: https://ecommons.aku.edu/pakistan_fhs_son

Part of the Counseling Commons, Female Urogenital Diseases and Pregnancy Complications Commons, Nursing Midwifery Commons, Obstetrics and Gynecology Commons, $\underline{\text { Public Health }}$ $\underline{\text { Commons, }}$ and the Sociology Commons

\section{Recommended Citation}

Ali, S. A., Mawani, M., Bano, G., Ali, S. A. (2016). Important strategies for effective family planning counseling. Reproductive System \& Sexual Disorders, 5(3), 184-184.

Available at: https://ecommons.aku.edu/pakistan_fhs_son/344 


\section{Important Strategies for Effective Family Planning Counseling}

Savera Aziz Ali ${ }^{1}$, Minaz Mawani ${ }^{2}$, Gulshan Bano ${ }^{3}$ and Sumera Aziz Ali ${ }^{3^{*}}$

${ }^{1}$ School of Nursing and Midwifery, Aga Khan Hospital, Karachi, Pakistan

${ }^{2}$ Department of Medicine, Aga Khan University Hospital, Karachi, Pakistan

${ }^{3}$ Department of Community Health Sciences, Aga Khan University Hospital, Karachi, Pakistan

"Corresponding author: Ali SA, Department of Community Health Sciences, Aga Khan University Hospital, Karachi, Pakistan, Tel: +92 2134930051 ; E-mail: sumera.ali@aku.edu

Rec date: July 13, 2016; Acc date: July 18, 2016; Pub date: July 25, 2016

Copyright: @ 2016 Ali SA, et al. This is an open-access article distributed under the terms of the Creative Commons Attribution License, which permits unrestricted use, distribution, and reproduction in any medium, provided the original author and source are credited.

Citation: Ali SA, Mawani M, Bano G, Ali SA (2016) Important Strategies for Ef fective Family Planning Counseling. Reprod Syst Sex Disord 5: 184. doi: $10.4172 / 2161-038 X .1000184$

\section{To Editor,}

Counseling is one of the important domains to promote the health and well-being of individuals. Counseling can be done for different purposes including personal hygiene antenatal care, and family planning [1]. Counseling about family planning is a challenging skill which is learned by the health care providers during their training period and later on they use their skill to ensure that client's reproductive health is maintained [2].

The holistic approach of counseling is considered as a comprehensible approach theoretically but sometimes it becomes difficult to apply in real life [3]. Counseling is more than a suggestion and it is highly important to develop an insight in a client about her problem [4].

Firstly in-depth assessment regarding the use of contraceptive methods and root cause analysis of method failure need to be done for effective counseling. Secondly, in-depth assessment of client needs by involving both partners is also important. Husband's involvement is essential during counseling because pregnancy planning is the joint responsibility of couple. The support from client's partner is very important for adapting any contraceptive method. The quality of couple's relationship and inter-spousal communication and its effect on contraceptive use has been supported by literature [5]. Spousal communication has been identified as a good predictor of counseling for contraceptive use [6].

Futhermore, theoretical knowledge needs to be applied practically and a lot of practice is required to convince the clients in an ethical way. Moreover, an expert opinion of the experts is always required regarding family planning counseling by integrating different approaches to family planning counseling $[7,8]$. Such sensitive issues need to be discussed with the client by having enough knowledge about the contraceptive methods. Furthermore, a strong rapport needs to be established with clients to discuss sexual and reproductive health related issues without hesitation [9]. Lastly, client should be given multiple options to select the method for herself through informed choices [10]. The above-mentioned tips can make the counseling for Family Planning more effective to enhance the uptake of contraceptive methods.

\section{Acknowledgement}

This was written as a part of BsCN assignments at Aga Khan University.

\section{References}

1. Gavin L, Moskosky S, Carter M, Curtis K, Glass E, et al. (2014) Providing quality family planning services. MMWR Morbidity \& Mortality Weekly Report 63: 1-29.

2. Sarfraz M, Hamid S (2014) Challenges in delivery of skilled maternal careexperiences of community midwives in Pakistan. BMC pregnancy and childbirth 14: 59.

3. Hamilton JD (2014) Gestalt in pastoral care and counseling: A holistic approach: Routledge.

4. Sierra J (2014) Counseling: an expression of the ministry of the church. The Asbury Journal 69: 74-88.

5. Link CF (2011) Spousal communication and contraceptive use in rural Nepal: an event history analysis. Stud Fam Plann 42: 83-92.

6. Akanbi MA, Ogbari ME, Akinbola OA, Amusan TA, Ogunmiloro SF (2011) The effect of interspousal communication on contraceptive use among married couples in alimosho local government area of Ipaja, Lagos State, Nigeria. Society and Development 1: 29-36.

7. Hanna K, Rodger S (2002) Towards family-centred practice in paediatric occupational therapy: A review of the literature on parent-therapist collaboration. Australian Occupational Therapy Journal 49: 14-24.

8. Ettorre E (1999) Experts as 'storytellers' in reproductive genetics: exploring key issues. Sociology of Health \& Illness 21: 539-559.

9. McWilliam R, Tocci L, Harbin GL (1998) Family-centered services service providers' discourse and behavior. Topics in Early Childhood Special Education 18: 206-221.

10. Kim YM, Kols A, Mucheke S (1998) Informed choice and decision-making in family planning counseling in Kenya. Int Fam Plann Persp 24: 4-11. 